Images in...

\title{
Skin rash and pneumonia in a young male
}

\author{
Parvaiz A Koul, ${ }^{1}$ Umar H Khan, ${ }^{2}$ Fayaz A Sofi ${ }^{2}$ \\ ${ }^{1}$ Internal \& Pulmonary Medicine Department, SheriKashmir Institute of Medical Sciences, Srinagar, India; \\ 2Internal Medicine Department, SheriKashmir Institute of Medical Sciences, Srinagar, India
}

Correspondence toDr Parvaiz A Koul, parvaizk@gmail.com

\section{DESCRIPTION}

A 35-year-old male smoker presented with a 7-day history of fever, cough and mild breathlessness and an exanthematous eruption that appeared over his entire body, 2 days after the onset of symptoms. Two weeks prior to his illness, two of his children have had chickenpox, having recovered uneventfully. There was no history of vaccination. Examination revealed a febrile, tachpnoeic patient with a diffuse polymorphic skin rash with papules, vesicles and pustules; some showing evidence of crusting (figure 1). Auscultation of the chest revealed diffuse bilateral crepitations. Radiograph of the chest revealed discreet nodular and confluent infiltrates throughout the lung fields more towards the bases and hilar regions (figure 2). Serologic testing for HIV was negative. Based on typical rash, pulmonary symptoms and contact with children with chickenpox, a diagnosis of varicella pneumonia was made. The patient was treated with intravenous acyclovir. Follow-up radiography at 1 week showed marked improvement. The patient had an uneventful recovery. Varicella pneumonia is the most serious complication of chickenpox in adults, being 25 -times commoner than in children. ${ }^{1}$ Potentially refractory, fulminant respiratory failure can ensue. Patients

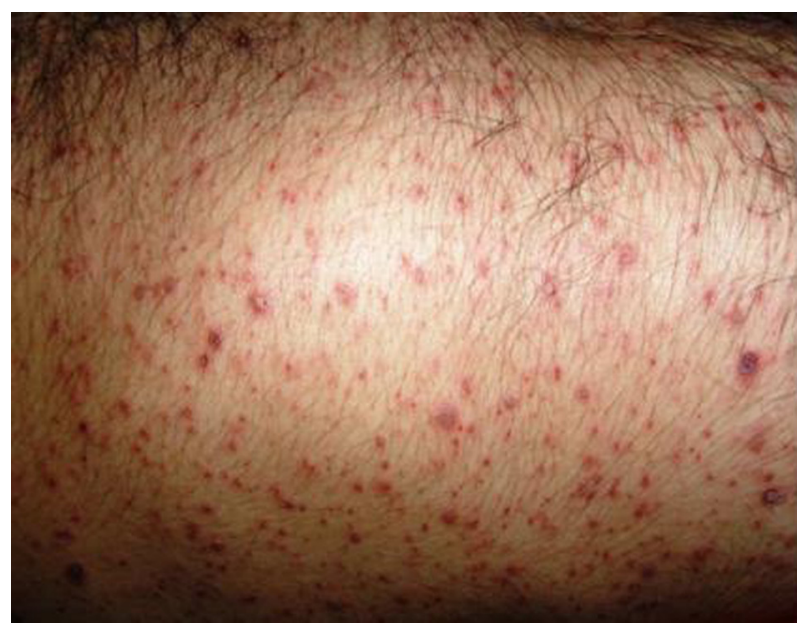

Figure 1 Skin lesions (polymorphic rash). with impaired immune status and chronic lung disease are at an increased risk. ${ }^{23}$ Long-term complications include a restrictive lung disease with reduced forced expiratory volume in one second and diffusing capacity of lung for carbon monoxide and presence of clinically insignificant calcifications on radiology. ${ }^{1}$ Mortalities have decreased over the years from $19 \%$ in the 1960 s to about $6 \%$ in recent years ${ }^{1}$ primariy due to better experience with the disease, antiviral chemotherapy and better ventilation facilities.

Competing interests None.

Patient consent Obtained.

\section{REFERENCES}

1. Mohsen AH, McKendrick M. Varicella pneumonia in adults. Eur Respir $J$ 2003;21:886-91.

2. Popara M, Pendle $S$, Sacks $L$, et al. Varicella pneumonia in patients with HIV/ AIDS. Int J Infect Dis 2002;6:6-8.

3. Ong EL, Mulvenna P, Webb KA. Varicella-zoster infection in adults with cystic fibrosis: role of acyclovir. Scand J Infect Dis 1991;23:283-5.

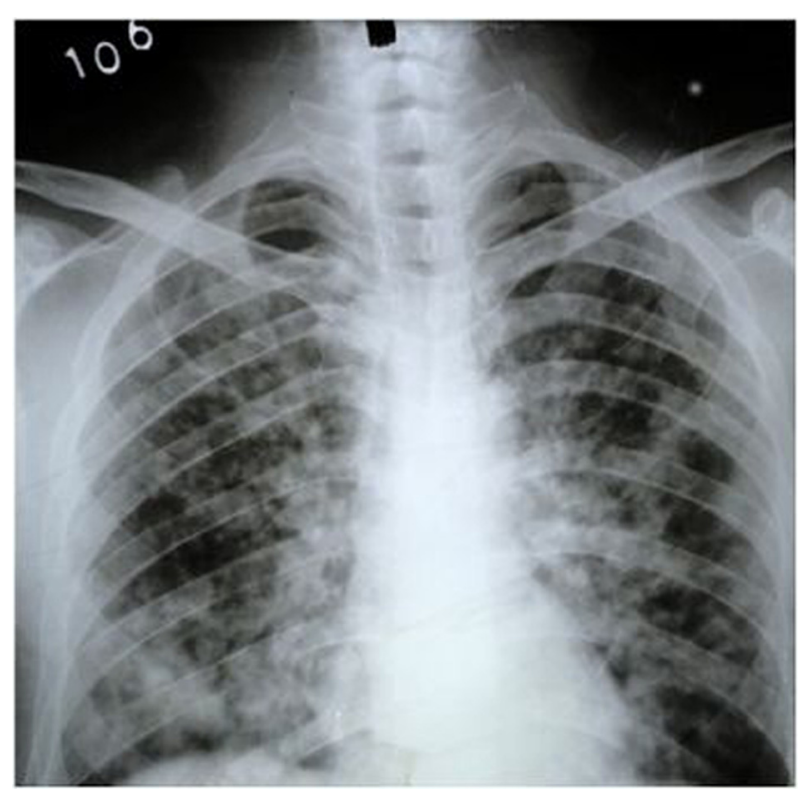

Figure 2 Bilateral infiltrates in lung fields. 


\section{BMJ Case Reports}

This pdf has been created automatically from the final edited text and images.

Copyright 2011 BMJ Publishing Group. All rights reserved. For permission to reuse any of this content visit http://group.bmj.com/group/rights-licensing/permissions.

BMJ Case Report Fellows may re-use this article for personal use and teaching without any further permission.

Please cite this article as follows (you will need to access the article online to obtain the date of publication).

Koul PA, Khan UH, Sofi FA. Skin rash and pneumonia in a young male. BMJ Case Reports 2011;10.1136/bcr.07.2011.4558, date of publication

Become a Fellow of BMJ Case Reports today and you can:

- Submit as many cases as you like

- Enjoy fast sympathetic peer review and rapid publication of accepted articles

- Access all the published articles

- Re-use any of the published material for personal use and teaching without further permission

For information on Institutional Fellowships contact consortiasales@bmjgroup.com

Visit casereports.bmj.com for more articles like this and to become a Fellow 